\title{
Pengaruh Mobilisasi Dini Terhadap Penyembuhan Luka Perineum Ruptur Tingkat II Pada Ibu Post Partum di Puskesmas Kassi-Kassi Makassar Tahun 2019
}

\author{
${ }^{\mathbf{1}}$ Nurjannah Supardi, ${ }^{2}$ Fitri Yani \\ ${ }^{12}$ Fakultas Keperawatan dan Kebidanan, Universitas Megarezky \\ Makassar, Indonesia, 90234 \\ E-mail: ${ }^{1}$ nurjannahsupardi90@gmail.com
}

\begin{abstract}
Perineal injuries result from natural tissue damage due to the pressure on the fetus's head or shoulders during labor. Early Mobilization helps the recovery process to the way it was before pregnancy, guiding the mother out of bed and walking as quickly as possible. The purpose of this study was to determine the effect of early mobilization on the healing of level II ruptured perineal wounds in post partum mothers at Kassi-Kassi Makassar Health Center in 2019. The research was carried out in February May 2019. This type of research is quantitative with a cross sectional study approach. A population of 83 people and a sample of 30 respondents with purposive sampling technique. The results showed that of the 30 respondents, 19 people did early mobilization (63.3\%), 11 people did not do early mobilization (36.7\%). ), and those who had good healing of perineal wounds were 21 people (70.0\%), and 9 people (30.0\%) had poor healing. There is an effect of early mobilization on the healing of level II ruptured perineal wounds in post partum mothers with a value of $p=0.004<\alpha=0.05$. It is hoped that the mother should carry out early mobilization so that they can understand the technique and carry out early mobilization movements so that the mother can do it alone.
\end{abstract}

Keywords: Early Mobilization, Perineal Wounds

\begin{abstract}
Abstrak
Luka perineum diakibatkan rusaknya jaringan secara alamiah karena proses desakan kepala janin atau bahu pada saat proses persalinan. Mobilisasi Dini membantu proses pemulihan seperti semula sebelum kehamilan, membimbing ibu keluar dari tempat tidur dan selekas mungkin segera berjalan. Tujuan dalam penelitian ini untuk mengetahui pengaruh mobilisasi dini terhadap penyembuhan luka perineum ruptur tingkat II pada ibu post partum di Puskesmas Kassi-Kassi Makassar Tahun 2019 Penelitian dilaksanakan pada bulan Februari - Mei 2019. Jenis penelitian ini adalah bersifat kuantitatif dengan pendekatan cross sectional study. Populasi berjumlah 83 orang dan sampel 30 responden dengan tehnik pengambilan sampe Purposive Sampling Hasil penelitian menunjukkan bahwa dari 30 orang responden, yang melakukan mobilisasi dini sebanyak 19 orang $(63,3 \%)$, yang tidak melakukan mobilisasi dini sebanyak 11 orang $(36,7 \%)$, dan yang memiliki penyembuhan baik terhadap luka perineum sebanyak 21 orang $(70,0 \%)$, yang kurang baik sebanyak 9 orang $(30,0 \%)$. Ada pengaruh mobilisasi dini terhadap penyembuhan luka perineum ruptur tingkat II pada ibu post partum dengan nilai $p=0.004<\alpha=0,05$ Diharapkan kepada ibu agar melakukan mobilisasi dini agar dapat memahami
\end{abstract}




$$
\begin{array}{cl}
\text { Vol 9, No 2 (2020), 5-13 } \\
\text { Jurnal Kesehatan } & \begin{array}{l}
\text { ISSN 2301-5683 (print) } \\
\text { E-ISSN 2775-9423 (online) } \\
\text { DOI: 10.31314/mjk.9.2.5-13.2020 }
\end{array}
\end{array}
$$

\section{Available Online at http://journal.umgo.ac.id/index.php/madu}

teknik dan melakukan gerakan mobilisasi dini supaya ibu dapat melakukannya sendiri tanpa bantuan tenaga kesehatan.

Kata Kunci: Mobilisasi Dini, Luka Perineum 


\section{PENDAHULUAN}

Masa nifas dimulai setelah 2 jam postpartum dan berakhir ketika alat-alat kandungan kembali seperti keadaan sebelum hamil, biasanya berlangsung selama 6 minggu atau 42 hari, namun secara keseluruhan baik secara fisiologis maupun psikologis akan pulih dalam waktu 3 bulan (1).

Luka perineum didefinisikan sebagai adanya robekan jalan lahir secara spontan maupun secara episiotomi pada saat melahirkan janin Bahaya dan komplikasi ruptur perineum antara lain perdarahan, infeksi, dan disparenia (nyeri selama berhubungan seksual). Perdarahan pada ruptur perineum dapat menjadi hebat khusunya pada ruptur derajat I dan III atau jika ruptur perineum meluas ke samping atau naik ke vulva mengenai klitoris (2).

Ruptur perineum dapat dihindarkan atau dikurangi dengan menjaga jangan sampai dasar paanggul dilalui oleh kepala janin dengan cepat dan tindakan terkendali. Sebaliknya kepala janin yang akan lahir jangan ditahan terlampau kuat dan lama, karena akan mengakibatkan asfiksia dan perdarahan dalam tengkorak janin, serta melemahkan otot-otot dan fasia pada dasar panggul, karena direnggangkaan terlalu lama (3). Ruptur perineum dialami oleh $85 \%$ wanita yang melahirkan pervagina. Pada golongan umur 25-30 tahun yaitu 24\% sedang pada ibu bersalin usia 32-39 tahun sebesar 62\%. Ruptur perineum perlu mendapat perhatian karena dapat menyebabkan disfungsi organ reproduksi wanita, sebagai sumber perdarahan dan sumber jalan keluar masuknya infeksi, yang kemudian dapat menyebabkan kematian karena perdarahan (4).

Berdasarkan survey demografi kesehatan indonesia (SDKI) pada tahun 2014, angka kematian ibu di Indonesia yaiu 359 per 100.000 kelahiran hidup. Sedangkan pada tahun 2015 angka kematian ibu di Indonesia yaitu 315 per 100.000 kelahiran hidup dan pada tahun 2016 angka kematian ibu di Indonesia yaitu 305 per 100.000 kelahiran hidup (5)

Data yang diperoleh dari Dinas Kesehatan Provinsi Sulawesi Selatan pada tahun 2015. Jumlah ibu nifas sebanyak 1500 orang dengan angka kematian ibu sebanyak 120 orang ibu. Pada tahun 2016 jumlah ibu nifas sebanyak 3000 orang ibu dengan angka kematian menjadi 160 atau 110,26 per kalahiran hidup, terdiri dari kematian ibu hamil 45 orang $(28,1 \%)$, kematian ibu bersalin 60 orang $(40 \%)$ kematian ibu nifas 55 orang (30\%), kajadian ruptur 5\% sehingga terjadi perdarahan yang mengakibatkan kematian (6). Salah satu faktor yang dapat mempengaruhi penyembuhan adalah mobilisasi dini. Mobilisasi dini adalah suatu pergerakan, posisi atau adanya kegiatan yang dilakukan ibu setelah beberapa jam melahirkan. Adapun tujuan mobilisasi dini adalah untuk membantu jalannya proses pemulihan seperti semula sebelum terjadi kehamilan. Mobilisasi dini tidak hanya mempercepat kesembuhan luka perineum tetapi juga memulihkan kondisi tubuh ibu jika dilakukan dengan benar dan tepat. Mobilisasi dini atau gerakan sesegera mungkin bisa mencegah aliran darah terhambat. Hambatan aliran darah bisa menyebabkan terjadinya thrombosis vena 


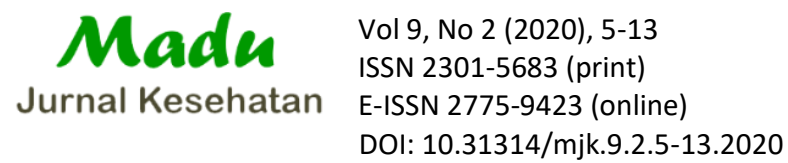

Available Online at http://journal.umgo.ac.id/index.php/madu

dalam (deep vein trombosis) dan menyebabkan infeksi (7).

Dari uraian diatas maka dilakukan penelitian yang bertujuan unutk mengetahui pengaruh mobilisasi dini terhadap penyembuhan luka perineun ruptur tingkat II pada ibu post partum di Puskesmas Kassi-Kassi Makassar Tahun 2019.

\section{METODE PENELITIAN}

Berdasarkan ruang lingkup permasalahan dan tujuan penelitian maka jenis penelitian kuantitatif, dengan menggunakan metode penelitian yaitu desain penelitian Analitik dengan pendekatan Cross Sectional Study yaitu jenis penelitian yang menekankan pengukuran Observasi Variabel independen dan dependen dilakukan dalam waktu yang bersamaan.

Rancangan penelitian ini adalah

\begin{tabular}{lll} 
Umur & $\begin{array}{l}\text { Frekuensi } \\
\text { (f) }\end{array}$ & $\begin{array}{l}\text { Persentase } \\
(\%)\end{array}$ \\
\hline 20-25 Tahun & 11 & $\mathbf{3 6 , 7}$ \\
\hline 26-35 Tahun & 19 & $\mathbf{6 3 , 3}$ \\
\hline Total & $\mathbf{3 0}$ & $\mathbf{1 0 0}$
\end{tabular}

berupaya mengungkapkan pengaruh antara variabel suatu penelitian dimana variabel independennya adalah mobilisasi dini sedangkan variabel dependennya adalah penyembuhan luka perineum pada ibu post partum.
Penelitian ini dilakukan di Puskesmas Kassi-Kassi Makassar. Penelitian ini dilakukan pada bulan tanggal 1 Februari - 1 Mei 2019 yang dilaksanakan di Puskesmas Kassi-kassi Makassar yang di dapatkan populasi sejumlah 83 orang dan sampel 30 responden. Penelitian ini dilakukan pada bulan tanggal 1 Februari - 1 Mei 2019 yang dilaksanakan di Puskesmas Kassi-kassi Makassar yang di dapatkan populasi sejumlah 83 orang dan sampel 30 responden. Populasi dalam penelitian ini adalah seluruh ibu post partum yang berada di Puskesmas Kassi-Kassi Makassar pada bulan 1 Februari - 1 Mei 2019 yang berjumlah 83 orang.

Sampel dalam penelitian ini adalah sebagian ibu post partum yang mengalami ruptur perineum tingkat II yang berada di Puskesmas Kassi-Kassi Makassar pada bulan 1 Februari -1 Mei 2019 yang berjumlah 30 responden. Pada penelitian ini data dianalisa menggunakan uji univariat, uji bivariat dan Uji Chi - Square menggunakan aplikasi SPSS.

\section{HASIL PENELITIAN}

\section{Karakteristik Responden berdasarkan Umur}

Sumber :Data Primer 2019

Tabel 1 menunjukkan bahwa dari 30 responden, umur 20-25 tahun 11 responden (36,7 \%) dan umur 26-35 tahun 19 responden (63,3\%). 
2. Karakteristik Responden berdasarkan Paritas

\begin{tabular}{lll} 
Paritas & $\begin{array}{l}\text { Frekuensi } \\
\text { (f) }\end{array}$ & Persentase (\%) \\
\hline Primipara & 8 & $\mathbf{2 6 , 7}$ \\
\hline Multipara & 22 & $\mathbf{7 3 , 3}$ \\
\hline Total & $\mathbf{3 0}$ & $\mathbf{1 0 0}$ \\
\hline
\end{tabular}

Sumber :Data Primer 2019

Tabel 2 menunjukkan bahwa dari 30 responden, paritas primipara sebanyak 8 responden $(26,7 \%)$ dan multipara sebanyak 22 responden (73,3\%).

\section{Karakteristik Responden berdasarkan} Pendidikan

\begin{tabular}{lll} 
Pendidikan & $\begin{array}{l}\text { Frekuensi } \\
(\mathrm{f})\end{array}$ & $\begin{array}{l}\text { Persentase } \\
(\%)\end{array}$ \\
\hline SD & 5 & $\mathbf{1 6 , 7}$ \\
\hline SMP & 7 & $\mathbf{2 3 , 3}$ \\
\hline SMA & 14 & $\mathbf{4 6 , 6}$ \\
\hline D3 & 2 & $\mathbf{6 , 7}$ \\
\hline S1 & 2 & $\mathbf{6 , 7}$ \\
\hline Total & $\mathbf{3 0}$ & $\mathbf{1 0 0}$ \\
\hline
\end{tabular}

Sumber :Data Primer 2019

Tabel 3 menunjukkan bahwa dari 30 responden, tingkat pendidikan SD sebanyak 5 responden $(16,7 \%)$, tingkat pendidikan SMP sebanyak 7 responden (23,3\%), tingkat pendidikan SMA sebanyak 14 responden $(46,6 \%)$, D3 sebanyak 2 responden $(6,7 \%)$ dan S1 sebanyak 2 responden $(6,7 \%)$.

\section{Karakteristik Responden berdasarkan Pekerjaan}

\begin{tabular}{lll} 
Pekerjaan & $\begin{array}{l}\text { Frekuensi } \\
\text { (f) }\end{array}$ & $\begin{array}{l}\text { Persentase } \\
(\%)\end{array}$ \\
\hline IRT & 23 & $\mathbf{7 6 , 6}$ \\
\hline
\end{tabular}

7. Hasil Analisa Bivariat (Uji Chi- Square)

\begin{tabular}{lll}
\hline Wiraswasta & 5 & 16,7 \\
\hline PNS & 2 & 6,7 \\
\hline Total & 30 & 100 \\
\hline
\end{tabular}

Sumber :Data Primer 2019

Tabel 4 menunjukkan bahwa dari 30 responden, IRT sebanyak 23 responden (76,6\%). wiraswasta 5 responden $(16,7 \%)$. PNS sebanyak 2 responden (6.7\%).

\section{Hasil Analisis Univariat Mobilisasi} Dini

\begin{tabular}{lll}
$\begin{array}{l}\text { Mobilisasi } \\
\text { Dini }\end{array}$ & $\begin{array}{l}\text { Frekuensi } \\
\text { (f) }\end{array}$ & $\begin{array}{l}\text { Persentase } \\
(\%)\end{array}$ \\
\hline Ya & 19 & $\mathbf{6 3 , 3}$ \\
\hline Tidak & 11 & $\mathbf{3 6 , 7}$ \\
\hline Total & $\mathbf{3 0}$ & $\mathbf{1 0 0}$ \\
\hline
\end{tabular}

Sumber :Data Primer 2019

Tabel 5 menunjukkan bahwa dari 30 responden yang melakukan mobilisasi dini sebanyak 19 responden $(63,3 \%)$ dan yang tidak melakukan mobilisasi dini sebanyak 11 responden $(36,7 \%)$.

6. Penyembuhan Luka Perineum

\begin{tabular}{lll}
$\begin{array}{l}\text { Penyembuhan } \\
\text { Luka Perineum }\end{array}$ & $\begin{array}{l}\text { Frekuensi } \\
\text { (f) }\end{array}$ & $\begin{array}{l}\text { Persentase } \\
(\%)\end{array}$ \\
\hline Baik & 21 & $\mathbf{7 0}$ \\
\hline Kurang Baik & 9 & $\mathbf{3 0}$ \\
\hline Total & $\mathbf{3 0}$ & $\mathbf{1 0 0}$
\end{tabular}

Sumber :Data Primer 2019

Tabel 6 menunjukkan bahwa dari 30 responden, yang memiliki penyembuhan baik terhadap luka perineum sebanyak 21 responden $(70 \%)$ dan yang kurang baik sebanyak 9 responden (30\%). 


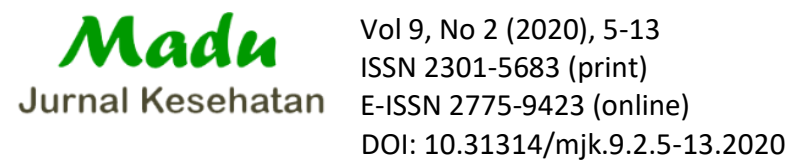

Available Online at http://journal.umgo.ac.id/index.php/madu

\begin{tabular}{|c|c|c|c|c|c|c|c|}
\hline \multirow{3}{*}{ Mobilisasi Dini } & \multicolumn{4}{|c|}{$\begin{array}{l}\text { Penyembuhan Luka } \\
\text { Perineum }\end{array}$} & & & \multirow{3}{*}{ Nilai $p<a$} \\
\hline & \multicolumn{2}{|c|}{ Baik } & \multicolumn{2}{|c|}{$\begin{array}{l}\text { Kurang } \\
\text { Baik }\end{array}$} & \multicolumn{2}{|c|}{ Jumlah } & \\
\hline & $\mathrm{n}$ & $\%$ & $\mathrm{n}$ & $\%$ & $\mathrm{n}$ & $\%$ & \\
\hline Ya & 17 & 89,5 & 2 & 10,5 & 19 & 100 & \\
\hline Tidak & 4 & 36,4 & 7 & 63,6 & 11 & 100 & $0.004<0,05$ \\
\hline Total & 21 & 70,0 & 9 & 30,0 & 30 & 100 & \\
\hline
\end{tabular}

Sumber : Data primer 2019 
Tabel 7 menunjukkan bahwa dari 19 responden yang melakukan mobilisasi dini, terdapat 17 responden $(89,5 \%)$ yang memiliki penyembuhan baik pada luka perineum, dan 2 responden $(10,5 \%)$ yang memiliki penyembuhan kurang baik pada luka perineum. Sedangkan yang tidak melakukan mobilisasi dini sebanyak 11 responden, terdapat 4 responden $(36,4 \%)$ yang memiliki penyembuhan baik pada luka perineum, dan 7 responden $(63,6 \%)$ yang memiliki penyembuhan kurang baik pada luka perineum. Dengan pengujian menggunakan teknik Chi-Square didapatkan $\mathrm{p}=0,004$ lebih kecil dari $\alpha=$ 0,05, ini berarti Ho ditolak dan Ha diterima. Dengan demikian ada pengaruh mobilisasi dini terhadap penyembuhan luka perineum ruptur tingkat II pada ibu post partum.

\section{PEMBAHASAN}

Mobilisasi dini adalah suatu pergerakan, posisi atau adanya kegiatan yang dilakukan ibu setelah beberapa jam melahirkan dengan persalinan normal. Mobilisasi dini adalah kebijaksanaan untuk sedini mungkin membimbing penderita keluar dari tempat tidur dan berjalan setelah persalinan. Selain resiko diatas, dampak yang dapat terjadi bila mobilisasi dini tidak dilakukan adalah kurangnya suplai darah dan pengaruh hipoksia pada luka. Dengan ibu melakukan mobilisasi dini akan memperlancar sirkulasi atau suplai darah keseluruh tubuh, pada saat terjadi luka jaringan atau sel pada daerah yang terjadi luka tersebut menjadi rusak, dengan adanya suplai darah yang baik akan mempercepat vaskularisasi.
Vaskularisasi yaitu pembuluh darah yang menyuplai oksigen yang berfungsi memperbaiki fungsi jaringan yang rusak, dengan adanya oksigen yang baik dalam tubuh berfungsi sebagai zat pembakar dalam tubuh sehingga dapat meningkatkan suhu dalam tubuh semakin besar suplai oksigen dalam tubuh maka akan lebih meningkatkan suhu dalam tubuh dengan adanya peningkatan suhu tubuh yang akan membuat proses penyembuhan luka (8).

Luka dengan suplai darah yang buruk akan sembuh dengan lambat. Jika faktor-faktor esensial untuk penyembuhan, seperti oksigen, asam amino, vitamin dan mineral, sangat lambat mencapai luka karena lemahnya vaskularisasi, maka penyembuhan luka tersebut akan terhambat, Perlukaan perineum umumnya terjadi unilateral, namun dapat juga bilateral. Perlukaan pada diafragma urogenitalis dan muskulus levatorani, yang terjadi pada waktu persalinan normal atau persalinan vagina, sehingga tidak kelihatan dari luar (9).

Dalam penelitian ini didapatkan hasil dari 19 responden yang melakukan mobilisasi dini, terdapat 17 responden $(89,5 \%)$ yang memiliki penyembuhan baik dan 2 responden $(10,5 \%)$ yang memiliki penyembuhan kurang baik. hal tersebut dikarenakan ibu kurang menjaga personal hygiene, dalam mengganti pembalut dan menjaga kebersihan bagian luka perineum sehingga luka dalam $\geq 5$ hari masih tampak basah. Hasil penelitian ini sejalan Garniati (2016) di RS. Pelita Harapan Banjarmasin menunjukkan bahwa dari 51 orang yang dijadikan sebagai sampel, terdapat 39 orang yang melakukan mobilisasi dini dengan 


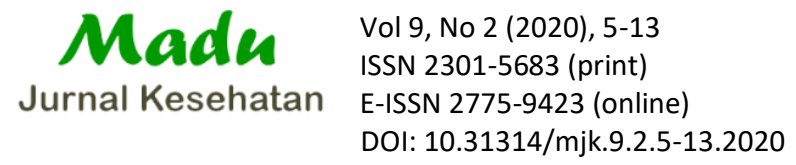

Available Online at http://journal.umgo.ac.id/index.php/madu

perkembangan luka perineum baik dengan nilai $\mathrm{p}=0,002$ yang berarti Ho ditolak dan Ha diterima.

Hasil penelitian diatas menunjukkan bahwa hasil yang diperoleh sejalan dengan penelitian yang dilakukan dimana pada hasil penelitian lebih banyak yang melakukan mobilisasi dini mengalami proses penyembuhan dengan cepat. Begitupun dengan hasil penelitian sebelumnya yang dilakukan oleh Wida Aprilia dan Mutmainnah bahwa terdapat 25 orang yang mengalami proses penyembuhan luka secara cepat dan pada penelitian yang dilakukan oleh Mutmainnah terdapat 23 orang yang mengalami proses penyembuhan luka secara cepat. Oleh karena itu penelitian yang dilakukan oleh peneliti sudah sejalan dengan penelitian sebelumnya.

Untuk itu dibutuhkan teknik pernyembuhan yang benar dan hati-hati untuk mencegah terjadinya infeksi dan luka jahitan perineum. Peneliti berasumsi bahwa hasil penelitian yang kami lakukan sejalan dengan teori dimana teori mengatakan bahwa mobilisasi sangat erat kaitannya dengan penyembuhan luka perineum begitupun dengan hasil penelitian terdahulu. Namun perlu disadari bahwa tidak sedikit dari jumlah populasi ibu yang melakukan mobilisasi dini akan mengalami komplikasi penyulit dalam menghadapi persalinan dan kelahiran. Serta dapat menghambat proses penyembuhan luka pada perineum.

\section{KESIMPULAN}

Dari hasil penelitian dilaksanakan pada bulan Februari 2019 di Puskesmas Kassi-Kassi Makassar. Jenis penelitian ini adalah bersifat kuantitatif dengan pendekatan Cross Sectional Study maka diperoleh kesimpulan bahwa ada pengaruh mobilisasi dini terhadap penyembuhan luka perineum ruptur tingkat II pada ibu post partum.

\section{SARAN}

Setelah dilakukan penelitian dan didapatkan kesimpulan maka penulis memberikan beberapa saran sebagai berikut:

1. Diharapkan kepada ibu agar dalam melakukan mobilisasi dini untuk memahami teknik dan cara melakukan gerakan mobilisasi dini supaya ibu dapat melakukannya sendiri tanpa bantuan tenaga kesehatan

2. Diharapkan kepada bidan yang bertugas di bagian nifas agar lebih meningkatkan perhatiannya dalam memberikan informasi tentang mobilisasi dini. Diharapkan kepada pihak Puskesmas KassiKassi Makassar agar lebih menekannkan kepada bidan yang bertugas khususnya diruangan nifas agar lebih meningkatkan perhatian serta informasi kepada ibu nifas untuk melakukan mobilisasi dini

3. Diharapkan kepada pihak institusi khususnya Universitas Megarezky 
Makassar agar menekankan kepada mahasiswa untuk melakukan asuhan pada masa nifas pada saat mereka turun praktek di lahan agar dapat menerapkan pelayanan khususnya ibu nifas yang melakukan mobilisasi dini.

4. Diharapkan pada peneliti selanjutnya agar meneliti variabel yang lain serta menggunakan metode penelitian yang lain

5. Diharapkan pada peneliti selanjutnya agar meneliti variabel yang lain serta menggunakan metode penelitian yang lain.

\section{DAFTAR PUSTAKA}

1. Wiknjosastro H, Saifuddin AB, Rachimhadhi T. Ilmu Kebidanan. 3rd ed. Jakarta: YBP-SP; 1999.

2. Nurazizah. Ruptur Perineum.

Sukabumi; 2014.

3. Enggar. Asuhan Kebidanan Pada Masa Nifas. Yogyakarta: Pustaka Pelajar; 2014.

4. Chapman V, Charles C. Persalinan dan Kelahiran : Asuhan Kebidanan. 2nd ed. Jakarta: EGC; 2013.

5. Dinas Kesehatan. Survei Demografi Kesehatan Indonesia. Makassar; 2016.

6. Dinas Kesehatan. Profil Kesehatan Sulawesi Selatan. Makassar; 2014.

7. Manuaba, Gede IB. Ilmu

Kebidanan/Penyakit Kandungan dan

KB. 2nd ed. Jakarta: EGC; 2014.

8. Suparyanto L. Efektifitas senam hamil sebagai pelayanan prenatal dalam menurunkan kecemasan menghadapi persalinan pada primigravida. J Fak Psikol. 2012;8(2).

9. Morison, Moya J. Manajemen Luka. Cetakan Pertama. Jakarta: EGC; 2013. 